\title{
Slovak Republic: Financial System Stability Assessment Update, including Reports on the Observance of Standards and Codes on the following topics: Banking Supervision and Insurance Regulation
}

This update to the Financial System Stability Assessment on Slovak Republic was prepared by a staff team of the International Monetary Fund and the World Bank as background documentation for the periodic consultation with the member country. It is based on the information available at the time it was completed on May 22, 2007. The views expressed in this document are those of the staff team and do not necessarily reflect the views of the government of Slovak Republic or the Executive Board of the IMF.

The policy of publication of staff reports and other documents by the IMF allows for the deletion of market-sensitive information.

To assist the IMF in evaluating the publication policy, reader comments are invited and may be sent by e-mail to publicationpolicy@imf.org.

Copies of this report are available to the public from

International Monetary Fund • Publication Services

700 19th Street, N.W. • Washington, D.C. 20431

Telephone: (202) $6237430 \bullet$ Telefax: (202) 6237201

E-mail: publications@imf.org • Internet: http://www.imf.org

Price: $\$ 18.00$ a copy

\section{International Monetary Fund} Washington, D.C. 



\title{
INTERNATIONAL MONETARY FUND
}

\author{
SLOVAK REPUBLIC
}

\section{Financial System Stability Assessment Update}

\author{
Prepared by the Monetary and Capital Markets Department \\ Approved by Jonathan Fiechter and Susan Schadler
}

May 22, 2007

This Financial System Stability Assessment (FSSA) Update is based on the work of the joint IMF/World Bank Financial Sector Assessment Program (FSAP) update mission that visited Bratislava from November 29 to December 12, 2006.

The FSAP team comprised Mark O’Brien (mission chief, IMF), Sonja Brajovic-Bratanovic (deputy mission chief, World Bank), Joseph Crowley, Vassili Prokopenko (both IMF), Heinz Rudolph, Eric van der Plaats (both World Bank), Rob Bakker (insurance expert, formerly Dutch Insurance and Pensions Supervisory Authority), Keith Bell (bank supervision expert, formerly Canadian Supervisory Authority), Jörg Genner (bank supervision expert, German Supervisory Authority), Tyge Rasmussen (securities market expert, formerly Copenhagen Stock Exchange), and Shannon Bui (administrative assistant, IMF). The mission received excellent cooperation and support from the authorities. The main findings of the FSAP update are:

- $\quad$ Financial intermediation in Slovakia has continued to deepen. Solid progress has been achieved since the 2002 FSAP in strengthening the supervisory and regulatory framework.

- $\quad$ Banking system financial soundness indicators are good, and stress tests indicate that banks remain resilient to a range of possible adverse shocks.

- While rapid, the rate of credit growth presently seems manageable. In contrast to many other Central and Eastern European countries, lending is funded to a large degree by domestic deposits and is predominantly denominated in local currency.

- Nonbank financial institutions are growing quickly but the sector as a whole is still small and not currently a source of systemic vulnerability. The securities markets are also small and with limited liquidity.

The main authors of this report are Mark O’Brien and Vassili Prokopenko.

FSAPs are designed to assess the stability of the financial system as a whole and not that of individual institutions. They have been developed to help countries identify and remedy weaknesses in their financial sector structure, thereby enhancing their resilience to macroeconomic shocks and cross-border contagion. FSAPs do not cover risks that are specific to individual institutions such as asset quality, operational or legal risks, or fraud. 
Glossary ………

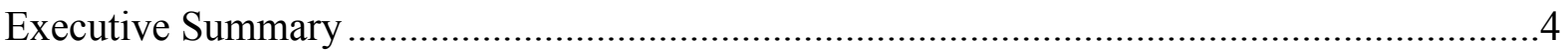

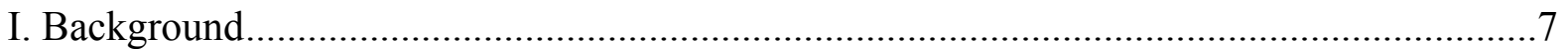

A. Summary of the 2002 FSAP Findings .................................................................

B. Recent Developments in the Financial Sector..........................................................

II. Sources of Potential Risk to Financial Stability...............................................................

A. Macroeconomic Environment.......................................................................

B. Major Counterparties of Slovak Financial Institutions ............................................13

III. Strengths and Vulnerabilities: Institutions and Markets ..................................................16

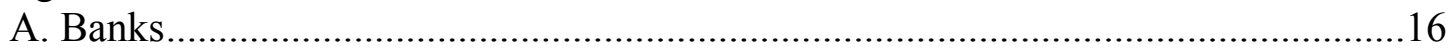

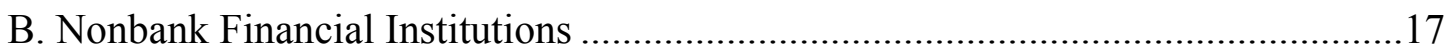

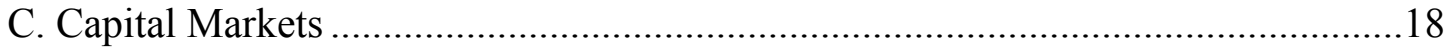

IV. Strengths and Vulnerabilities: the Financial Stability Policy Framework..........................19

A. Regulatory and Supervisory Frameworks.........................................................19

B. NBS's Publications on Financial Stability Analysis ............................................20

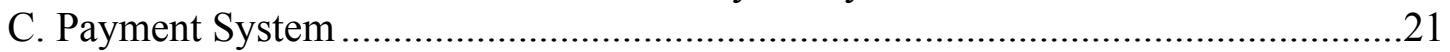

D. Systemic Liquidity Management and Safety Nets ..................................................21

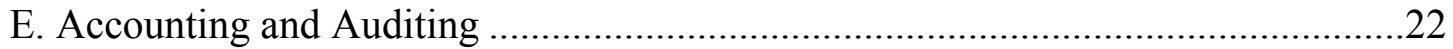

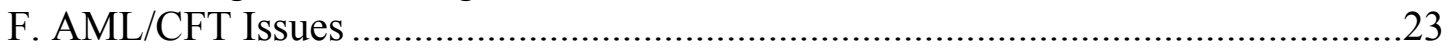

Tables

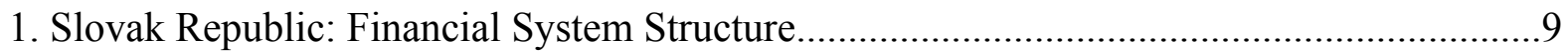

2. Slovak Republic: Core Financial Soundness Indicators for the Banking Sector..................11

3. Slovak Republic: Additional Financial Soundness Indicators...........................................12

Figures

1. Slovak Republic: Selected Financial Sector Indicators ..................................................10

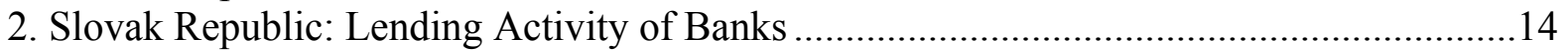

Appendixes

I. Slovak Republic: Status of the Main Recommendations of the 2002 FSAP .........................35

II. Stress Tests: Overview of the Shocks and Results............................................................

Annexes

Summary Assessments of Observance of Selected Financial Sector Standards. 


\section{GLOSSARY}

\begin{tabular}{ll} 
BA & Banking Act \\
BCP & Basel Core Principle for Effective Banking Supervision \\
BSSE & Bratislava Stock Exchange \\
CEE & Central and Eastern Europe \\
CESR & Committee of European Securities Markets Regulators \\
CRD & Capital Requirements Directive \\
DPF & Deposit Protection Fund \\
EU & European Union \\
ECB & European Central Bank \\
EMU & European Monetary Union \\
FMA & Financial Markets Authority \\
FSIs & Financial Soundness Indicators \\
FSR & Financial Stability Review \\
IAIS & International Association of Insurance Supervisors \\
ICPs & IAIS Insurance Core Principles \\
IFRS & International Financial Reporting Standards \\
ISAs & International Standards on Auditing \\
IT & Information technology \\
MIFID & Markets in Financial Instruments Directive \\
MOF & Ministry of Finance \\
MTPL & Motor third party liability \\
MTS & EU trading platform for Euro-denominated governments' bonds \\
NBS & National Bank of Slovakia \\
NMS & New member states \\
NPLs & Nonperforming loans \\
PFMCs & Private pension fund management companies \\
RRSFSA & Report on the Results of Slovak Financial System Analysis \\
RTGS & Real time gross settlement system \\
SBCB & Slovak Bank Credit Bureau \\
SCSD & Slovak Central Securities Depository \\
SEPA & Single Europe Payments Area \\
SME & Small and medium sized enterprises \\
EU-15 & Core European member states \\
& \\
\hline
\end{tabular}




\section{EXECUTIVE SUMMARY}

The Slovak financial sector has been growing rapidly as the depth of financial intermediation trends towards developed country norms following the bank restructuring and privatization program of the early 2000s. Commercial banks are by far the dominant financial institutions, though non-bank financial institutions have grown faster than the banks in recent years, and the securities markets remain small.

Financial soundness indicators (FSIs) present a picture of a robust banking system. Capital adequacy ratios (CARs) have been falling - which is to be expected given their relatively high levels following the reforms - but they are still at healthy levels. Increased competition in the banking sector has contributed to improved access to credit for households and SMEs, and also to reduced interest rate spreads and banks' fee levels. So far at least, the increased competition has not led to any significant lowering of credit standards.

Although rapid, the rate of bank credit growth seems appropriate, given the strong outlook for the economy. Furthermore, in contrast to some neighboring countries, lending is predominantly in local currency, so that banks are not exposed to indirect foreign currency risk. Nevertheless, banking system fragilities could appear in future if the rapid rate of credit growth continues for an extended period. The supervisory framework currently appears to be adequate to identify and monitor any risks that do arise from this source.

Stress tests confirm that the banks are currently resilient to a range of possible adverse shocks. Reflecting the current healthy capital position of the banking system, none of the sensitivity and scenario stress tests considered would bring the average Tier I capital adequacy of the system below 10 percent.

While the performance of the insurance sector has been good overall, the level of technical provisions for part of the life insurance industry is relatively low. In particular, technical provisions for many older life policies with guaranteed capital need to be increased, to reflect that interest rates have fallen further than was assumed at the time they were written. There is also a need for the supervisor to monitor the capital adequacy on life insurance policies closely. Relatedly, the highly competitive market for motor third party liability (MTPL) insurance is limiting companies' ability to raise premia in that sector, which will also require close monitoring.

A new multi-pillar pension system was introduced in 2005 , aimed at making the Slovak social security system sustainable, but some challenges remain. Investment returns for pillar 2 pension funds have been low to date, and actions may be needed to encourage higher returns through greater diversification. Changes in the regulations covering governance and competition would also facilitate higher returns. The Government should also consider starting preparations for the payout phase of the pension system.

The securities markets in Slovakia are small and illiquid. As integration with the EU deepens, corporate entities in Slovakia will be able to access markets in Western Europe with 
increasing ease. While this raises questions regarding the future of the domestic securities market in Slovakia, it does not seem to be a cause for concern.

The supervisory and regulatory framework has been significantly improved since 2002 . Although progress has been faster in some areas than others, the gaps that do exist are not likely to undermine the National Banks of Slovakia's (NBS's) capability to effectively perform its supervisory responsibilities. The FSAP mission's assessments of the Basel Core Principles (BCP) for the banking sector and the International Association of Insurance Supervisors (IAIS) Insurance Core Principles (ICPs) indicate that there is general compliance in virtually all applicable areas. The NBS seems prepared for application of risk-based supervision and to start implementation of Basel II. The unification of supervision under the NBS that commenced in 2006 should help to address the areas of supervision where comparatively less progress has been made.

The financial sector infrastructure has also been strengthened. The NBS' oversight of the payment system has seen further improvements and a real time gross settlement subsystem has been developed. Slovakia has also fully implemented the International Financial Reporting Standards (IFRS) for financial institutions, and auditing is now subject to International Standards on Auditing. While a driving factor for much of the improvement in both supervision and financial infrastructure has been the need to harmonize with EU standards, it also reflects the authorities' strong commitment to creating a well-functioning and well-supervised financial system.

\section{A few challenges, however, remain to be addressed in the near to medium term, especially in the area of financial institution supervision:}

- $\quad$ There will be a need to continue to upgrade supervisory expertise, and increasingly focus on risk-based supervision, as the financial sector continues to evolve and become more sophisticated;

- Integrated supervision has the potential to significantly enhance the quality of supervision, but the approaches to supervision across the different financial subsectors will need to integrated well to ensure these gains are achieved; and

- $\quad$ The problems in late 2005/early 2006 experienced by the foreign parent bank of one of the Slovak banks served to illustrate the supervisory challenges faced by small countries with largely foreign-controlled banking sectors. Resolving these challenges will require strengthened cooperation between home- and host-supervisors. This may be facilitated, at least for European Union (EU) member countries, by greater coordination at the EU level.

The main recommendations from the Slovakia FSAP Update are provided in Box 1. 


\section{Box 1. Slovak Republic: FSAP Update Recommendations}

\section{Short term/ongoing}

\section{Regulatory and supervisory framework}

- Continue integration of supervision through implementation of a risk-based approach for all intermediaries supervised by NBS, and through creating a common supervisory approach within the NBS through the dissemination of general supervisory principles across different financial subsectors.

- Continue monitoring closely prudential indicators and banks' credit assessment standards, so as to be prepared to take such actions as necessary to address any risks that may emerge.

- Work to strengthen coordination and lines of communication between the NBS and home country supervisors, especially regarding Basel II implementation.

\section{Insurance sector}

- Enhance the supervision of capital adequacy ratios of life insurance policies.

\section{Medium term}

\section{Regulatory and supervisory framework}

- Provide the NBS with the power to bar persons who come into positions of responsibility in existing banks and who do not meet fit and proper tests.

- Ensure fit and proper tests and enforcement for the nonbank financial institutions, including insurance companies.

\section{Insurance sector}

- Ensure adequate technical provisions.

- Define in law the supervisory responsibilities of external insurance auditors and actuaries.

\section{Financial sector infrastructure}

- Ensure that the IFRS financial reporting framework is fully implemented for financial sector entities.

\section{Second pillar pension funds}

- Provide incentives for diversification of pension fund portfolios.

\section{Capital markets}

- Develop a debt management strategy that includes fewer but larger bond issues and following the standards established for government bond-issues in large Euro markets.

- Decide on a strategy for the development of the Slovak capital market and the future of the Bratislava stock exchange.

\section{Consumer protection}

- Review and fine tune the legal and institutional structure for consumer protection. 


\section{BACKGROUND}

\section{A. Summary of the 2002 FSAP Findings}

1. The 2002 FSAP team noted a number of regulatory and supervisory challenges, but concluded that the overall challenges for the next period were more of a developmental than a stability nature. The FSAP team recommended that the Slovak authorities should emphasize risk-based supervision and improvement of supervisory practices; foster close cooperation among supervisory agencies including home country supervisory authorities; improve efficiency of exit processes and strengthen the collateral and insolvency regimes; improve the quality, breath, and depth of financial intermediation; and strengthen the financial sector infrastructure. With the country well along in preparation to join the EU, the 2002 FSAP team concluded that the Slovak financial system was not vulnerable to immediate macro-economic or financial sector shocks, but that some political and implementation risks were still present.

2. Most of the issues identified by the 2002 FSAP team have since been addressed. The regulatory framework has been improved, in order to address identified weaknesses as well as to achieve harmonization with the EU directives. Progress in adopting risk-based supervision has been somewhat uneven across sectors, but this is expected to be addressed by the unified supervisory framework established under the National Bank of Slovakia (NBS) in 2006. The financial sector infrastructure has been strengthened, including the legal framework for lending, and through the development of credit bureaus. There have also been significant improvements in accounting and auditing practices. Subsidies on mortgage interest rates were abolished in 2005. Appendix I summarizes how the key recommendations made by the 2002 FSAP have been addressed.

\section{B. Recent Developments in the Financial Sector}

3. Total assets of the Slovak financial sector have significantly expanded since 2002 (Figure 1 and Table 1). The system has become more diversified, as non-bank financial institutions (primarily pension funds, insurance companies, and securities companies) have grown faster than the banks, but the banks still remain by far the dominant institutions, accounting for more than 80 percent of financial system assets as of end-September 2006. The financial stability assessment presented in this report is therefore focused on banks and their counterparties.

4. Following the clean-up of banks' balance sheets in the early 2000s, the banking sector has been in a sound position (Tables 2 and 3 ). The aggregate capital adequacy ratio has been on a declining trend from the high level that prevailed after the recapitalization of banks, but it remains at a satisfactory level of around 13 percent. Profitability indicators are good, with an overall return on equity of 16.6 percent in 2006 that provides a further cushion to absorb any negative shocks that might arise. The nonperforming loan (NPL) ratio declined 
to 3.2 percent by end-2006, partly reflecting overall rapid credit growth and the change in early 2006 in the methodology for computing NPLs, but also the implementation of sound risk management practices, especially in the foreign-owned banks that dominate the system.

5. The banking sector is almost entirely foreign owned. Of the 17 banks registered in Slovakia in September 2006, only two very small institutions were locally owned. Foreign owners are typically well established banks from other EU countries, particularly Austria, Germany, and Italy. While subject to strong growth in recent years, banking sector assets, at around 95 percent of GDP, are still significantly lower than in the EU-15 but are in line with the New Member States (NMS) average.

\section{Concentration among commercial banks remains relatively high, which is not} unusual for an economy of a relatively small size. Three banks - owned by Erste Bank, Raiffeisen Zentral Bank (both Austrian), and Bank Intesa (Italian), respectively-dominate the market with a combined market share of around 50 percent of total banking system assets. Competition among banks has been increasing as evidenced by a generally declining concentration ratio (although there was some increase in 2006), and declining interest rate margins.

\section{Sources of Potential Risk to Financial Stability}

\section{A. Macroeconomic Environment}

\section{The current macroeconomic outlook does not pose immediate risks to financial} sector stability. As discussed in the accompanying Staff Report, real GDP growth has been buoyant and is expected to accelerate to above 8 percent in 2006, supported by robust domestic demand and an improved contribution from net exports. Although inflationary pressures intensified somewhat in 2006, and the fiscal deficit has risen to 3.4 percent of GDP (from 2.8 percent of GDP in 2005), the new government which took office as a result of the June 2006 general elections confirmed its commitment to adopt the Euro in January 2009 and meet all the Maastricht criteria. ${ }^{1}$ However, the Government's goal of boosting social spending as much as possible without breaching the Maastricht fiscal deficit criterion could create some inflationary pressures. The NBS increased its key policy rate by 175 basis points during 2006 (from 3 percent to 4.75 percent), and further interest rate hikes have not been ruled out.

\footnotetext{
${ }^{1}$ The five Maastricht criteria that EU countries must meet in order to adopt the Euro cover the inflation rate, the government deficit, government debt, long term interest rates, and the exchange rate. On March 16, 2007, the NBS and the ECB announced a 8.5 percent revaluation of Slovakia's ERM II central parity (see the context and policy discussions in the accompanying staff report).
} 


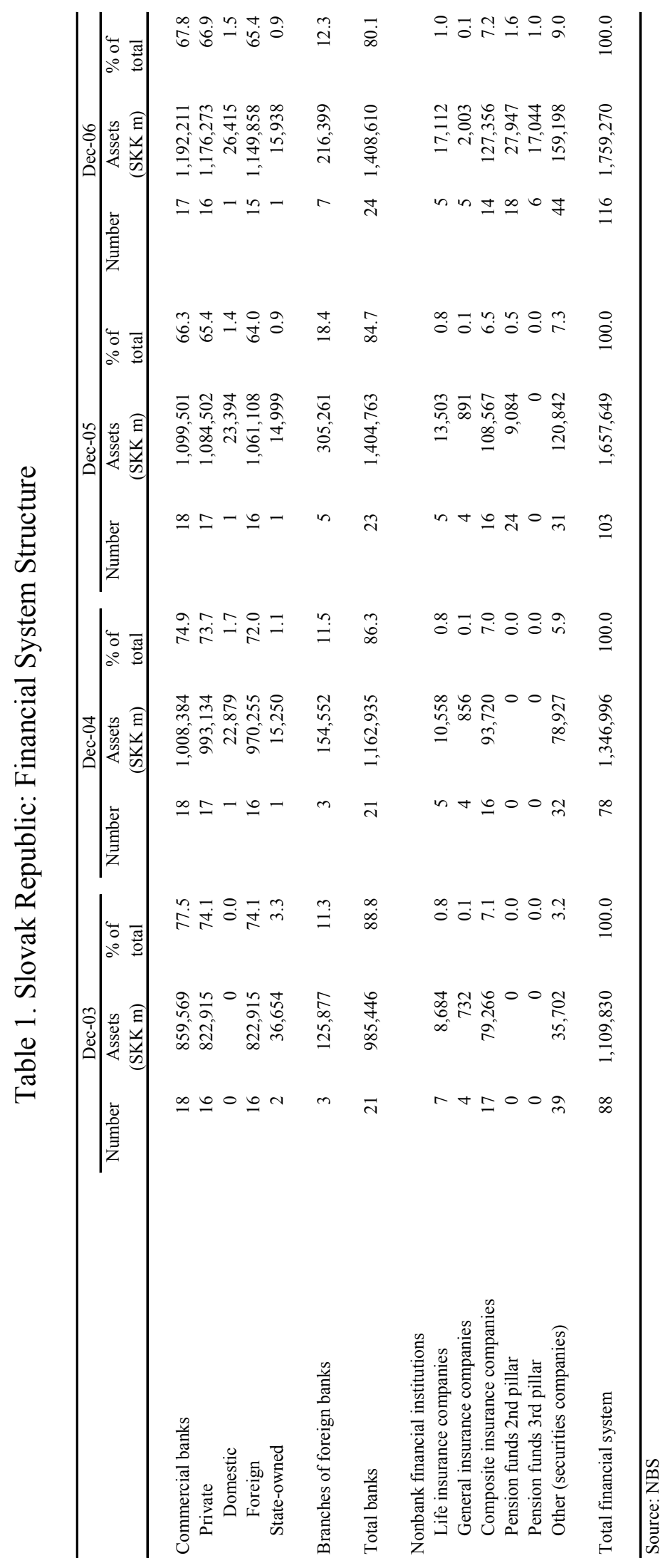


Figure 1. Slovak Republic: Selected Financial Sector Indicators

The financial sector is growing steadily ...

Assets of the financial system

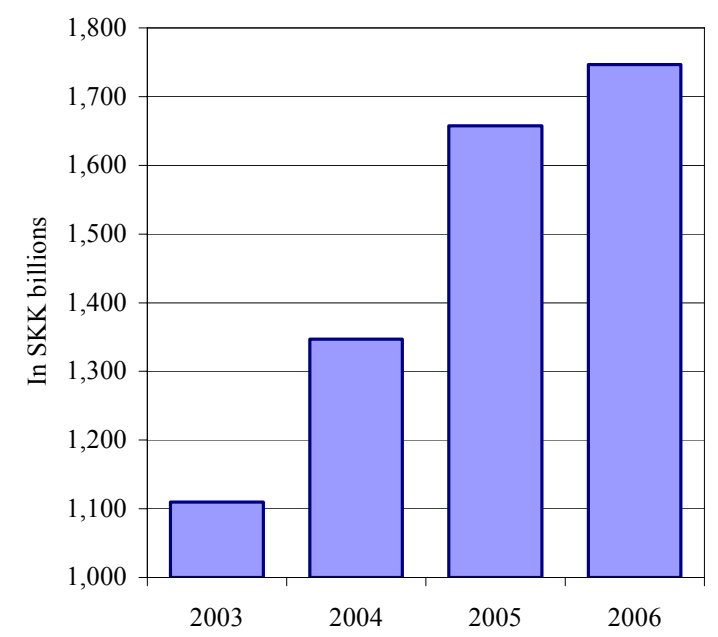

The depth of intermediation is at CEE average ...

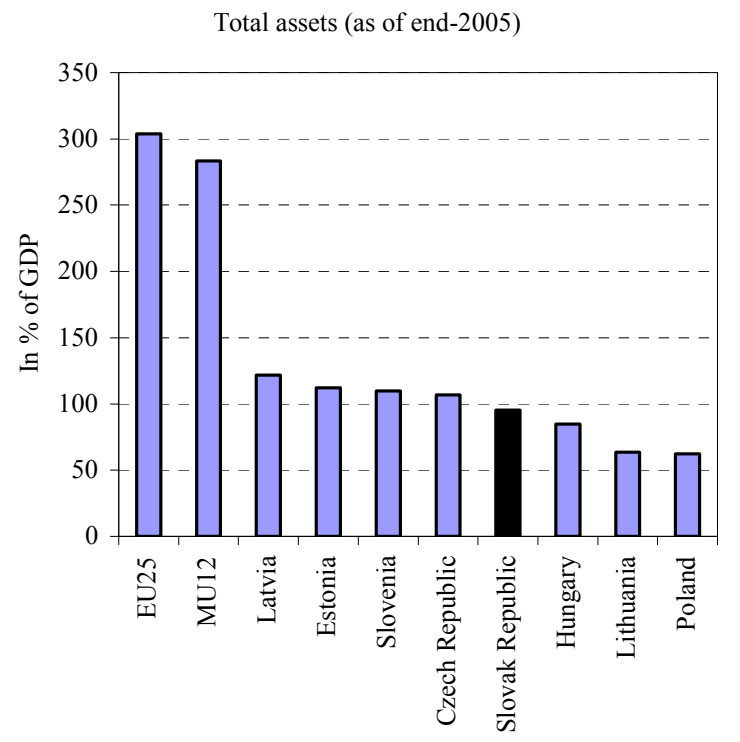

... and remains dominated by commercial banks

As of end-09/2006

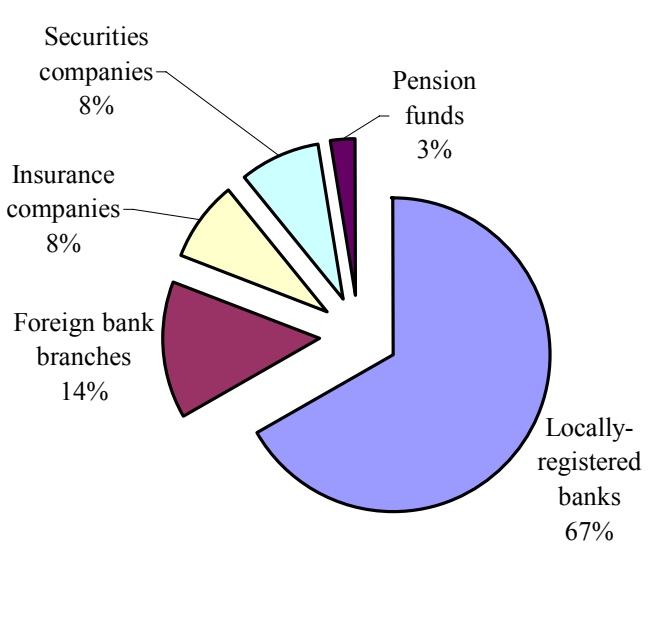

... and bank concentration is high but not excessive Herfindahl Hirschman Index 1/

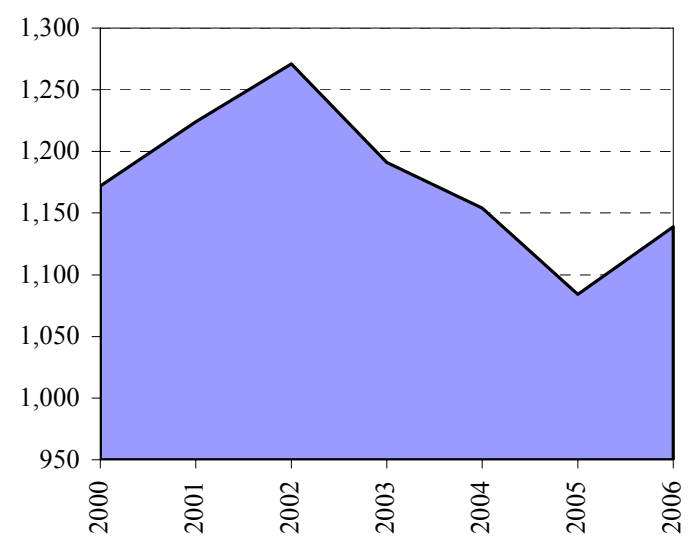

1/ As a rule of thumb, banking regulators in many countries (e.g., the United States) consider the value of the Herfindahl Hirschman Index (HHI) between 1,000 and 1,800 as an indication of a "somewhat concentrated" market structure. If the value of the $\mathrm{HH}$

Sources: NBS and ECB. 
Table 2. Slovak Republic: Core Financial Soundness Indicators for the Banking Sector (In percent, unless otherwise indicated)

\begin{tabular}{|c|c|c|c|c|c|}
\hline & Dec-02 & Dec-03 & Dec-04 & Dec-05 & Dec-06 \\
\hline \multicolumn{6}{|l|}{ Capital Adequacy } \\
\hline Regulatory capital to risk-weighted assets & 21.3 & 22.4 & 18.7 & 14.8 & 13.0 \\
\hline Regulatory Tier I capital to risk-weighted assets & 18.5 & 21.6 & 18.9 & 15.0 & 14.2 \\
\hline \multicolumn{6}{|l|}{ Asset Composition and Quality } \\
\hline NPLs to gross loans $1 /$ & 7.9 & 3.7 & 2.6 & 5.0 & 3.2 \\
\hline NPLs net of provisions to capital & 6.0 & 4.2 & 3.1 & 6.4 & 7.9 \\
\hline \multicolumn{6}{|l|}{ Sectoral distribution of loans (in $\%$ of total loans, stock) } \\
\hline Individuals & 18.1 & 21.7 & 26.7 & 30.3 & 30.2 \\
\hline Government & 3.3 & 2.9 & 8.3 & 5.0 & 2.5 \\
\hline Agriculture & 1.7 & 1.6 & 1.6 & 1.6 & 1.3 \\
\hline Manufacturing & 23.8 & 21.1 & 15.8 & 14.6 & 11.1 \\
\hline Construction & 1.7 & 1.4 & 1.6 & 2.2 & 2.5 \\
\hline Wholesale and retail trade & 14.9 & 13.1 & 13.5 & 13.0 & 11.9 \\
\hline Transportation & 6.7 & 8.1 & 5.1 & 3.9 & 4.7 \\
\hline Financial services & 6.3 & 6.9 & 8.7 & 10.3 & 18.3 \\
\hline Other & 23.4 & 23.2 & 18.7 & 19.1 & 17.3 \\
\hline \multicolumn{6}{|l|}{ Earnings and Profitability } \\
\hline ROA (after tax) 2/ & 1.2 & 1.2 & 1.2 & 1.2 & 1.3 \\
\hline ROE (after tax) 2/ & 11.5 & 10.8 & 11.9 & 16.9 & 16.6 \\
\hline Interest margin to gross income & 76.6 & 80.7 & 73.3 & 65.4 & 66.4 \\
\hline Noninterest expenses to gross income & 63.7 & 70.0 & 61.2 & 69.1 & 58.3 \\
\hline \multicolumn{6}{|l|}{ Liquidity } \\
\hline Liquid assets to total assets $3 /$ & 28.9 & 16.8 & 13.3 & 33.5 & 36.5 \\
\hline Liquid assets to short term liabilities & 81.3 & 55.9 & 40.3 & 40.3 & 45.6 \\
\hline \multicolumn{6}{|l|}{ Sensitivity to Market Risk } \\
\hline Net open positions in FX to capital (on balance sheet) & -42.0 & -59.0 & -80.0 & -14.4 & -1.2 \\
\hline Net open positions in FX to capital (off balance sheet) & -35.0 & 6.0 & 40.0 & -24.2 & 44.2 \\
\hline
\end{tabular}

1/ A decline in the NPL ratio in 2006 is partly due to a change in the methodology for calculating NPLs.

2/ Annualized for 2006.

3/ In 2006, liquid assets include government bonds in holding-to-maturity portfolio.

Source: NBS 
Table 3. Slovak Republic: Additional Financial Soundness Indicators (In percent, unless otherwise indicated)

\begin{tabular}{|c|c|c|c|c|c|}
\hline & Dec-02 & Dec-03 & Dec-04 & Dec-05 & Dec-06 \\
\hline \multicolumn{6}{|l|}{ Commercial banks } \\
\hline Capital to assets & 7.7 & 8.9 & 7.7 & 9.7 & 8.0 \\
\hline Foreign currency-denominated loans to total loans & 17.1 & 20.7 & 22.8 & 28.2 & 27.1 \\
\hline Foreign currency-denominated liabilities to total liabilities & 15.6 & 19.0 & 19.3 & 28.0 & 22.3 \\
\hline Gross asset position in financial derivatives to capital & n.a. & 9.0 & 16.0 & 12.3 & 26.6 \\
\hline Gross liability position in financial derivatives to capital & n.a. & 11.0 & 22.0 & 13.2 & 27.6 \\
\hline Annual growth of bank loans $1 /$ & 1.1 & 15.4 & 12.1 & 26.0 & 20.1 \\
\hline Trading income to total income & 36.0 & 26.5 & 35.6 & 18.5 & 14.9 \\
\hline Personnel expenses to noninterest expenses & 39.0 & 39.0 & 41.0 & 40.3 & 45.1 \\
\hline Spread between reference lending and deposit rates & n.a. & n.a. & 4.4 & 4.5 & 4.7 \\
\hline Customers deposits to (non-interbank) loans & n.a. & n.a. & 172.2 & 131.4 & 137.6 \\
\hline Net open positions in equities to capital & n.a. & n.a. & 0.3 & 1.3 & 0.6 \\
\hline \multicolumn{6}{|l|}{ Corporate sector } \\
\hline Total debt to equity & 341.9 & 293.0 & 230.9 & 217.0 & n.a. \\
\hline Return on equity & n.a. & n.a. & 0.8 & 1.0 & n.a. \\
\hline \multicolumn{6}{|l|}{ Households } \\
\hline Household debt to GDP & 15.9 & 17.0 & 16.5 & 21.8 & n.a. \\
\hline Household debt service and principal payments to income 2/ & n.a. & 2.3 & 3.2 & 3.8 & 4.2 \\
\hline \multicolumn{6}{|l|}{ Real Estate Markets } \\
\hline Real estate prices $3 /$ & n.a. & 39.6 & 15.4 & -9.2 & n.a. \\
\hline Residential real estate loans to total loans & n.a. & n.a. & n.a. & 19.9 & 30.1 \\
\hline Average loan to value ratio for real estate loans 4 / & n.a. & n.a. & 55 & 70 & n.a. \\
\hline \multicolumn{6}{|c|}{$\begin{array}{l}\text { 2/ Data for } 2006 \text { are for June. } \\
\text { 3/ Annual change in residential real estate prices per one squared meter. Source: National Association of Real Estate Agencies. } \\
\text { 4/ Data for } 2004 \text { are from the Mortgage register and include mortgage loans only. Data for } 2005 \text { and } 2006 \text { are from the Lending survey and cover all } \\
\text { housing loans issued by a group of banks which have a market share of around } 75 \text { percent. }\end{array}$} \\
\hline \multicolumn{6}{|l|}{ Source: NBS } \\
\hline
\end{tabular}

\section{The open nature of the Slovak economy means that international (particularly} Euro area) economic and financial developments are also important as potential risk factors. The current account deficit was 8.3 percent of GDP in 2006. However, exports are expected to pick up strongly as two new export-oriented automobile plants become fully operational from 2007, and as a result, the deficit should narrow substantially by $2008 .{ }^{2}$ In 2006, the deficit has been largely covered by non-debt creating flows (foreign direct investment), which makes Slovakia less exposed to an increase in global interest rates or an increase in risk aversion of foreign investors. However, Slovakia's macroeconomic performance will increasingly be dependent on the automobile manufacturing sector, which will leave the economy more vulnerable to global business cycle shocks.

\footnotetext{
${ }^{2}$ By the end of this decade, Slovakia is set to become the world's largest producer of cars on a per capita basis.
} 


\section{B. Major Counterparties of Slovak Financial Institutions}

9. There have been shifts in the relative importance of counterparties of Slovak financial institutions since 2002, resulting in parallel shifts in the structure of credit risks. Credit to households has grown consistently faster than credit to the corporate sector (in 2006, credit to households grew by 32 percent versus an overall growth rate in private sector credit of 20 percent). ${ }^{3}$ There has been an increase in the share of bank loans to nonbank financial institutions (consumer credit companies, leasing companies etc). These institutions are often subsidiaries of banks, and are thus supervised on a consolidated basis. While private sector credit has been growing fairly quickly, it reflects both robust GDP growth and a catching up to developed country intermediation norms, and the rate of growth does not seem excessive. ${ }^{4}$ Key trends are discussed below and illustrated in Figure 2.

\section{Household sector}

\section{The exposure of Slovak financial institutions to households has been growing} rapidly in recent years. As in other Central and Eastern Europe (CEE) countries, rapid growth in household lending has reflected increasing income as well as optimistic expectations of future income and wealth growth (related to the EU accession and anticipated Euro adoption), a decline in inflation and in nominal and real interest rates, and the structural shift from corporate to household lending. ${ }^{5}$ Interest rate subsidies on mortgage loans also played a role at the beginning of the cycle when interest rates were high, but these subsidies were abolished in 2005 after the rates significantly decreased.

\section{In contrast to many other CEE countries, there has been only limited foreign currency borrowing by Slovak households (less than 2 percent of all household loans are in foreign currencies), so that credit risks are lower. Low demand for foreign} currency loans is reported by local observers as due to deeply rooted risk aversion by Slovak households. However, it is likely also due in part to the conservative fiscal policy that has been followed in Slovakia in recent years. This policy has contributed to a more rapid convergence between Slovak and Euro interest rates than in most other emerging European countries, and thus a lower incentive to borrow in Euros.

\footnotetext{
${ }^{3}$ As banks' lending to households has consistently grown more rapidly than lending to corporates throughout the period, the stock of corporate loans has fallen from about 75 percent of banks' total loans as at end-2002 to a little over 60 percent by end-2006.

${ }^{4}$ Some other countries in the region have credit growth of more than 50 percent annually.

${ }^{5}$ In socialist economies, almost all bank lending was directed to corporates.
} 
Figure 2. Slovak Republic: Lending Activity of Banks

Bank loans are growing rapidly...

Stock of the private sector credit

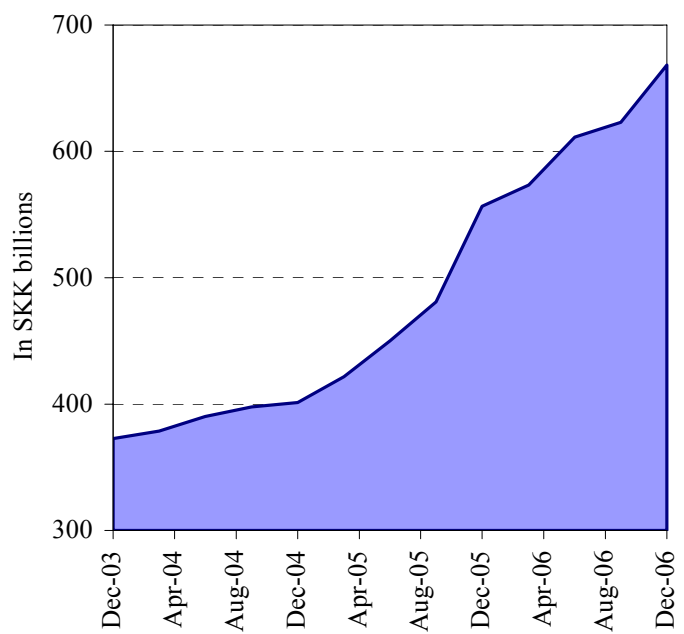

Household loans are mainly property-based loans ...

Household loans as of end-2006

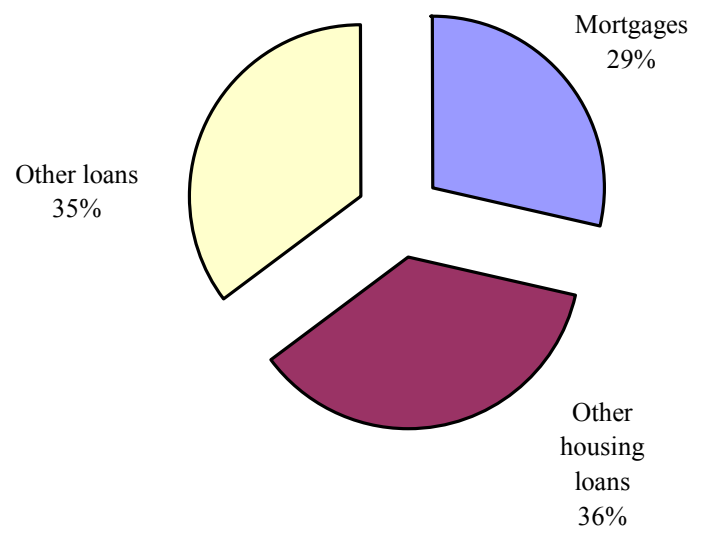

...driven by household lending

Annual growth

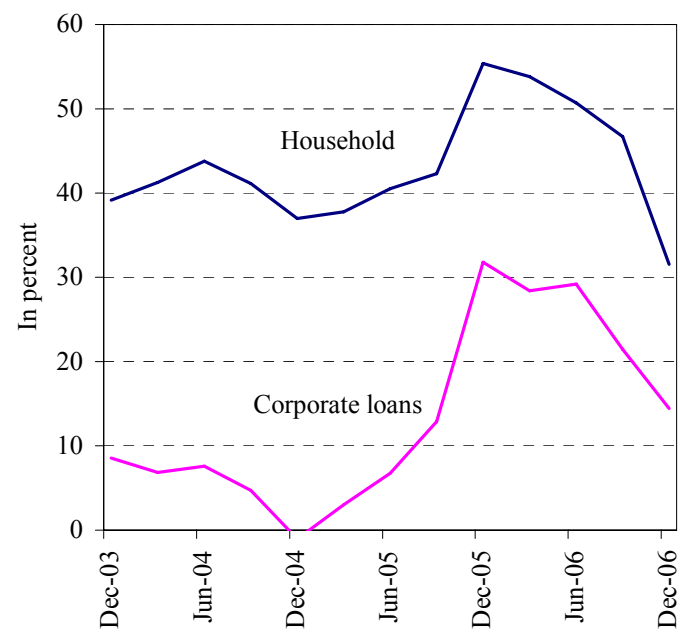

... and penetration of household loans is still low

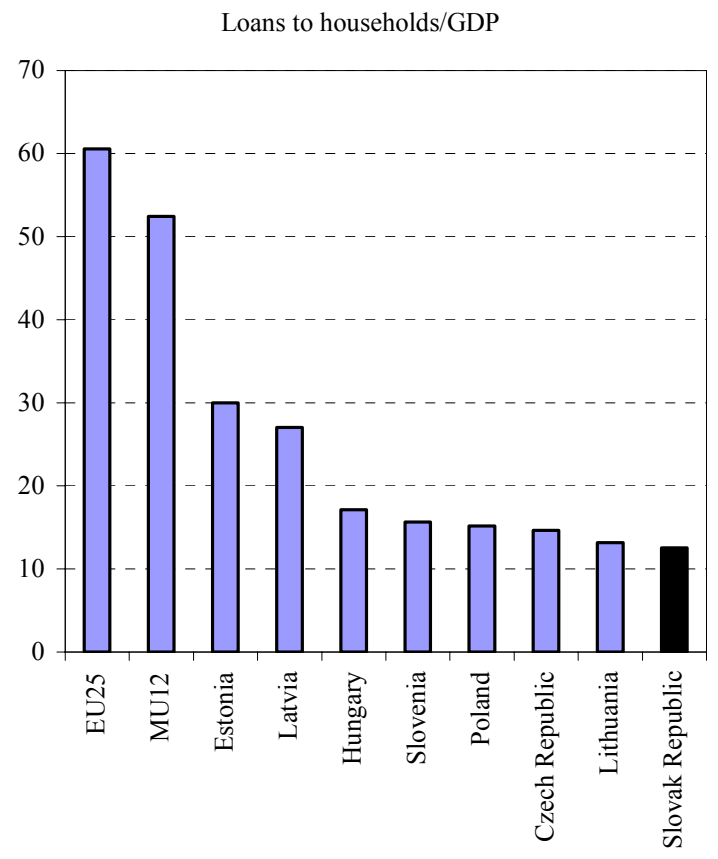

Sources: NBS and ECB. 


\section{Despite growing debt levels, the debt servicing capacity of households is}

manageable. The ratio of household debt to GDP, while steadily increasing, is still relatively low (22 percent in 2005). ${ }^{6}$ Most of the increase in household credit has been for mortgages, especially in the Bratislava region where household incomes have traditionally been the highest in the country. Coupled with the low exposure to foreign currency borrowing, the probability that a shock (e.g., an increase in unemployment) would significantly affect the debt servicing capacity is unlikely in the current environment.

\section{Corporate sector}

13. Growth in lending to the corporate sector was sluggish from 2003 to early 2005 , but has picked up more recently. The period of slow growth in corporate loans reflected, to some extent, banks' caution about lending to enterprises due to their previous experiences with corporate NPLs. Further, many Slovak enterprises had been able to self-finance their activities during the recent period of strong economic growth, while some of the larger enterprises (e.g., car plants, steel plant, electronics, chemical factories, etc.) have multinational owners that arrange the enterprises' financing needs from offshore. As a result, the leverage ratio of Slovak non-financial enterprises has been declining in recent years (Table 3). More recently, however, there are signs that some banks have begun lending to the mostly untapped SME market. Around one third of loans to corporates are denominated in foreign currencies, but a majority of these loans are reportedly to exporters so the loans provide a hedge to their foreign currency revenues.

\section{International exposures}

\section{Slovak banks' currently limited reliance on their foreign owners for funding} reduces their direct exposure to external developments and risks. Domestic deposits in Slovak banks are growing strongly (at an annual rate of 9 percent as of October 2006) and, in contrast to the situation in some other CEE countries, banks have relied only to a limited extent on funds from foreign banks for financing domestic loans.

\footnotetext{
${ }^{6}$ While average debt levels are low, anecdotal evidence indicates that a small proportion of households has much higher indebtedness. However, this does not present a significant source of risk.
} 


\section{STRENGTHS AND VULNERABILITIES: InSTITUTIONS AND MARKETS}

\section{A. Banks}

\section{Stress tests}

15. A set of stress tests was carried out by the NBS, based on scenarios proposed by the FSAP team, with the aim of analyzing the extent of the risks identified above. Appendix II provides a description of the tests that were undertaken, the methodology used, and the results.

16. The broad finding of the stress tests is that the Slovak banking system could withstand substantial market or credit shocks without facing difficulties. The banking system would be able to withstand a significant decline in real estate prices, and direct effects of exchange rate and interest rate volatility. The most significant effect on banks would result from a substantial shock to credit quality. ${ }^{7}$ An increase of NPLs to over 7 percent of total loans (doubling the NPLs), with a very conservative assumption of loss given default equal to 100 percent, would result in an aggregate loss of 21 percent of Tier I capital. ${ }^{8}$ Banks' incomes would likely provide some additional buffer to offset the impact of such a shock.

\section{The stress tests confirm the changing risk profile of the Slovak banking sector. A} comparison of the results based on end-September 2006 data with those of tests using data for previous years show that the exposure of Slovak banks to an increase in koruna interest rates has been increasing, largely because banks' portfolios of fixed interest rate bonds with longer maturities have increased faster than the duration of their liabilities (Appendix 2). The exposure to credit risk has been on a declining trend, reflecting the strengthening of banks' balance sheets.

\footnotetext{
${ }^{7}$ It should be noted that the magnitude of the assumed shocks under the stress tests for credit risk represents only a rough approximation of a possible deterioration in credit quality. Although the NBS has recently started developing a model capturing the relationship between macroeconomic variables, borrowers' solvency, and banking losses, such a model is not yet robust due to the absence of time-series data covering the whole business cycle. The stress tests performed as part of the FSAP update should therefore be viewed only as indicative of how the banking sector might be affected by adverse credit shocks.

${ }^{8}$ The assumption of loss given default of 100 percent is very conservative because many recently issued loans are well-collateralized mortgages, and the real estate market remains buoyant despite some stagnation in 2005.
} 


\section{B. Nonbank Financial Institutions}

\section{Insurance companies}

18. The Slovak insurance sector is developing but is still quite small. Assets are around 8 percent of total financial sector assets, which is broadly comparable to other countries in the region. Nearly all insurance companies are foreign owned and largely part of well reputed large insurance groups or financial conglomerates.

19. While the performance of insurance companies has been good overall, the level of technical provisions seems too low. In particular, as a result of declining interest rates (which reflects the prospects of joining the European Monetary Union), premia for earlier contracts for life policies with guaranteed capital appear to have been calculated using assumed less prudent (i.e., higher) discount rates. This means that these policies now require higher technical provisions. Technical provisions by third part liability automobile insurance companies also appear deficient since their privatization in the early 2000s, however a highly competitive market has limited the scope for a needed increase in premiums. The insurance supervisors are aware of these issues.

\section{Pension funds}

20. Private pension funds appeared in Slovakia following the pension system reform of 2005. As in many other CEE countries, a pension reform was introduced in response to the unsustainability of the "pay as you go" (PAYG) system. As well as reforming the existing PAYG (first) pillar to ensure its sustainability (through such measures as increasing the statutory retirement age), second (voluntary for existing workers but mandatory for new labor force entrants), and third (voluntary) pillars were also introduced. The second pillar is based on individual accounts in open pension funds managed by private pension fund management companies (PFMCs) and is still in the early stages of its accumulation phase. ${ }^{9}$ However, there are several issues - including the low rates of return that the second pillar funds have been generating to date - that should be addressed reasonably soon in order to ensure its sound development (Box 2).

\footnotetext{
${ }^{9}$ An "open pension fund" is one where there is no restriction on membership. i.e., membership is not limited to certain employees (e.g. those of an employer or group of employers). The new second pillar is mandatory for new workers, but voluntary for workers that were already in the labor force. As at end-2006, approximately two-thirds of the labor force had opted to participate in the second pillar.
} 


\section{Box 2. Slovak Republic: Further Development of the Pension Sector}

Several issues should be addressed in order to ensure the sound development of the new second pillar of the Slovak pension system. Specifically, steps should be taken to ensure further diversification of portfolios by, and to ensure a sound revenue base for, the PFMCs.

Up until now, the PFMCs have been investing second pillar funds primarily in very highly secure instruments, such as bank deposits and government bonds. This strategy may be aimed at convincing risk-averse individuals to participate in the new pillar. Irrespective of the reason, the real returns arising from this very low risk investment strategy have been low-between zero and 2 percent - in part because Slovak government security yields have to a large extent converged to Euro-levels. Consequently, the second pillar funds will need to diversify more into other instruments, including equities and foreign instruments.

There may also be a need to review whether the PFMCs, and their associated financial groups, are leveraging incomes from their pension management business. The relatively low management fees and consequent low margins for PFMCs have created incentives to seek other sources of revenue. Although, there is no tied cross-selling of pension products with products from other members of the same financial group, there may be some non-tied cross-selling in practice (e.g., marketing credit cards and other financial instruments, that have little relation with the pension business, to second pillar participants by PFMC parent companies). Marketing products in this way may create confusion for contributors about whether these products are tied to the pension product or not, and could also affect participants' future decisions regarding switching PFMCs.

In late 2006, there was some discussion of a proposal to switch part of the contributions from the second pillar to the first pillar. Subsequently, the Slovak government announced that there would be no reduction in second pillar contribution rates. While this issue now seems to have been dealt with, it is worth emphasizing that reductions in the contribution rate should be avoided. It would potentially undermine the viability of the second pillar (PFMCs are already operating with low margins due to the low mandated fees), and could create uncertainty for contributors regarding whether other changes might take place in the future.

\section{Capital Markets}

21. The capital markets in Slovakia are small and illiquid. Despite EU membership and developments in the regulatory framework and economic performance, the capital markets have not changed much in Slovakia since 2002. The most liquid segment is the government bond market, but it is dominated by only three to four active banks and has little secondary trading. The Bratislava Stock Exchange (BSSE) is now the only operating 
exchange in the country. A significant number of securities transactions is concluded through over the counter trading outside the BSSE and afterwards reported to the BSSE.

22. The market for mortgage bonds has been growing, but liquidity in the corporate bond and municipal bond markets is nearly nonexistent. ${ }^{10}$ There seems to be little possibility in the short term for developing a corporate bond market (other than for bank bonds) because the up-front costs and the small sizes of the issues makes them expensive relative to bank loans. Banks are also competing aggressively, so that they are providing a flexible funding source for companies.

23. The equity market is also inactive. There are only 13 listed companies, and their number has been decreasing due to takeovers. Market capitalization is low, with the estimated free float at no more than 15 percent. In addition to the listed market, there is a free market mainly stemming from the voucher privatization process, currently consisting of around 300 companies (down from about 800 in 2000). Trading activity is mainly done as pre-negotiated trades and has recently been falling in value.

\section{Strengths And Vulnerabilities: the Financial Stability Policy FRAMEWORK}

\section{A. Regulatory and Supervisory Frameworks}

\section{The regulatory and supervisory frameworks have been strengthened} significantly across all parts of the Slovak financial sector since the 2002 FSAP. This reflected the authorities' desire to better address the challenges and risks facing the Slovak financial system and to bring the legal framework in line with European laws as part of the EU accession process. As a result, financial sector regulations are of a high standard. As with other EU members, transposition of European directives into domestic law is an ongoing project.

\section{The reassessment of Basel Core Principles for Effective Banking Supervision} (BCP) showed a high level of observance (Annex). Whereas the 2002 FSAP found that there were significant weaknesses in banking supervision, the BCP reassessment found only minor shortcomings that do not hamper the NBS's capability to perform its supervisory tasks. The regulatory framework now complies with the requirements arising from EU directives, and the NBS seems well equipped to cope with the challenges resulting from the implementation of the Basel 2 capital framework. Cooperation and exchange of information with foreign supervisors have improved, but will become of even greater importance in the

\footnotetext{
${ }^{10}$ The present legislation requires banks to issue mortgage bonds for 90 percent of the mortgage loans.
} 
future. The NBS as the host supervisor in a small country is prepared and dedicated to efficiently support the consolidated supervisor to perform its tasks. The NBS is also well aware of the restricted influence it has in cross-border cooperation due to the limited impact the local institutions have on the risk profile of the groups of which they are a part.

26. Since the 2002 FSAP, insurance supervision has also shown an impressive improvement. As a result, insurance supervision has been found to be generally compliant with the International Association of Insurance Supervisors' Insurance Core Principles (Annex). Most of the 2002 FSAP recommendations have been implemented, in large part by transposing the European insurance directives in national legislation. The insurance supervisory staff of the NBS is fully aware of the both the spirit and the letter of this complex legislation. Collaboration with the Ministry of Finance in drafting legislation has also proven to be effective. Much effort is put into international cooperation with host supervisors, in order to understand and communicate the possible vulnerabilities within a cross-border operating insurance company, especially in light of the systemic role which some of these companies have in the Slovak market.

\section{Some aspects of the regulation of the second pillar pension system need,} however, to be strengthened. While many regulatory elements, such as investment regulations, are reasonably restrictive, the areas of governance, risk management, use of databases, and businesses with related parties seem rather liberal and impose unnecessary risks on pension funds. Although this has not implied a major threat for the pension system until now, regulatory improvements are needed in order to achieve an effective supervision and a proper incentive structure for PFMCs.

28. More generally, maintaining adequate and effective supervision in a fastchanging environment will remain an ongoing challenge. Increasing sophistication and complexity of market participants and financial instruments will require continuous upgrading of the skills of the NBS staff and a continuing dialogue of expertise and enhanced cooperation between Banking Supervision Department and other parties to keep the necessary expertise.

\section{B. NBS's Publications on Financial Stability Analysis}

29. Following the broad international trend, in the last four years the NBS began to produce two reports analyzing financial stability. The Research Department coordinates the preparation of Financial Stability Review (FSR, first published in 2003), and the Banking Supervision Department prepares Report on the Results of Slovak Financial System Analysis (RRSFSA, first issued in 2004). Both reports are published on a semi-annual basis, though the FSR is translated into English only once a year. 
30. While both these publications represent a significant step forward in the area of financial sector surveillance, there is some room for further improvement. Both reports do a good job in presenting overall assessment of financial sector trends, but some refinements could be considered to the content of these reports. More specifically, consideration could be given to significantly streamlining the presentation of both reports (which are now both well over 100 pages long) by sharpening the focus of the FSR on major risks and strengths/vulnerabilities of the Slovak financial system, while the RRSFSA could be centered around the analysis of structural developments and financial soundness indicators. The frequency of publication of these reports may also be revisited, with a more analytical FSR being published on an annual basis, while a more data-oriented RRSFSA remaining on a semi-annual or even quarterly basis.

\section{Payment System}

31. The payment system architecture, which has received high marks in the 2002 FSAP assessment, has seen further improvements. These include further strengthening of the NBS's oversight framework, development of the real time gross settlement subsystem, and intraday liquidity support. The NBS took over the operational responsibility for the Slovakia Interbank Payment Systems to ensure smooth, efficient, and safe operations. Another important initiative was to set national standards and integrate the national infrastructure related to electronic payment instruments. Credit card users in Slovakia are now able to use the shared network of automated teller machines, which has a potential to greatly facilitate integration in the single Europe payment area.

32. Further changes are under way to facilitate integration of Slovakia into the EU framework. The NBS has made significant progress in preparations to join the TARGET 2 real time gross settlement systems of the ECB by mid-2008. Another major initiative is an active participation in the Single Europe Payments Area Project (SEPA). The NBS is in the process of developing a national strategy for joining SEPA, which is expected to be completed by early 2007 .

\section{Systemic Liquidity Management and Safety Nets}

33. The modalities of liquidity management are similar to those in place at the time of the 2002 FSAP. The banking system remains very liquid, due in part to the NBS's sterilized purchases of capital inflows. As a result, the alternative channels of liquidity management (money and securities markets) have grown since 2002 but are still not very active or liquid. 
34. At the time of the 2002 FSAP, the Deposit Protection Fund (DPF) was insolvent, due to payouts to depositors of four failed banks in the 1999-2001 period. ${ }^{11}$ The shortfall was covered by a loan from the NBS. The 2002 FSAP team consequently recommended that the authorities develop a plan to bring the DPF to solvency, for example by replacing the NBS loan with capital provided by the Ministry of Finance. In the event, the NBS loan was taken over by a consortium of commercial banks, with amortization payments being made from the banking system's current contributions to the DPF. ${ }^{12}$ The contribution rate to the DPF was significantly increased for several years to speed the rate of loan repayment, but it was recently lowered again to eliminate any comparative disadvantage for the Slovak banks vis-à-vis those in neighboring EU member countries. The loan to the consortium will thus only be paid off by end-2010. In the event of the need for a payout before the DPF builds up significant funds again, it is likely the shortfall would again be covered by either the NBS or the rest of the banking system. As a result, while the DPF is designed as a fully funded scheme, it currently is operating to some extent as an ex-post funded scheme. Consideration could be given to some increase in the contribution rate, so as to build up the size of the DPF more quickly, while bearing in the comparative disadvantage issue.

\section{The failures of the four local banks, as well as the financial problems} experienced in 2005-2006 by one Austrian bank with a Slovak subsidiary, have contributed to the development of thorough contingency planning arrangements to deal with problem banks. ${ }^{13}$ A manual of emergency procedures that sets down the general principles that should be followed has been developed. A critical issue for the NBS in dealing with a problem in a systemically important bank will be the need for close cooperation with the home country supervisor. The experience with the Austrian bank showed that there is room for some improvement in this regard; however, the main impetus can only come from home supervisors.

\section{E. Accounting and Auditing}

36. As recommended by the 2002 FSAP, Slovakia has fully implemented the international financial reporting standards (IFRS) for financial sector entities. The new decrees, compliant with EU versions, mandate the use of IFRS for the preparation of individual and consolidated accounts of banks, insurance intermediaries, and listed companies. However, as the IFRS financial reporting framework includes a significant

\footnotetext{
${ }^{11}$ Since the 2002 FSAP, coverage of deposits was amended to be in line with EU minimum requirements, namely coverage at a rate of 90 percent up to a maximum of an equivalent of 20,000 Euros per account.

12 The Slovak budget law may make it difficult for the Ministry of Finance to provide funding to the DPF.

13 The experiences with the failed local banks also contributed to a significant strengthening in resolution procedures and laws, including Slovakia's insolvency laws.
} 
degree of professional judgment, this may result in differences in views on accounting treatments between supervisors, reporting companies, and their auditors, and may pose new challenges.

\section{The quality of auditing in the financial sector Slovakia is now covered} by International Standards on Auditing (ISAs). There is a system of external quality assurance and a disciplinary system. Slovakia Chamber of Auditors received donor funding to help with adoption of all ISAs, the IFAC code of ethics, and the International Audit Practice Statements relevant for the audit of financial statements of banks. By the end of 2006, all licensed audit firms will have been subject to quality controls/assurance and the disciplinary system has been renewed.

\section{F. AML/CFT Issues}

38. The anti-money laundering (AML) regime has been strengthened in recent years, but the recent assessment by MONEYVAL confirmed that some gaps remain that need to be addressed. The MONEYVAL assessment provides a number of useful and specific practical recommendations to address the remaining gaps in the AML/CFT framework in Slovakia and the authorities are urged to implement these recommendations. 


\section{Annex: Summary Assessments of ObServance of Selected Financial Sector STANDARDS AND CODES}

This annex contains a summary assessment of observance of the Basel Core Principles for Effective Banking Supervision (BCP) and the International Association of Insurance Supervisors (IAIS) Insurance Core Principles.

The detailed assessment of observance of the BCP was undertaken by Keith Bell (bank supervision expert, formerly Canadian Supervisory Authority) and Jörg Genner (bank supervision expert, German Supervisory Authority).

The detailed assessment of observance of the IAIS Insurance Core Principles was undertaken by Rob Bakker (insurance expert, formerly Dutch Insurance and Pensions Supervisory Authority).

Both assessments were based on several sources including:

- $\quad$ Self-assessments done by the Slovak authorities;

- $\quad$ Reviews of relevant legislation, decrees, regulations, policy statements and other documentation;

- $\quad$ Detailed interviews with the supervisory authorities;

- $\quad$ Meetings with other relevant authorities and independent bodies; and

- Meetings with financial sector firms and associations, including insurance companies, banks and securities firms and financial enterprises.

\section{A. Basel Core Principles for Effective Banking Supervision}

\section{The assessment of the observance of the Basel Core Principles for Effective} Banking Supervision was carried out as part of the Financial Sector Stability Assessment update mission to the Slovak Republic. The assessment was conducted in December 2006 in accordance with the guidelines set out in the Core Principles Methodology issued in October 2006. It reflected the banking supervision practices of the Slovak Republic authorities as of end-November 2006.

\section{Institutional and Macroprudential Setting, Market Structure-Overview}

\section{The financial sector of Slovakia is dominated by commercial banks, which} constitute nearly 88 percent of the financial sector's assets. The banking sector underwent a series of structural changes between 2001 and 2004, including the elimination of financially weak banks, the privatization of several others (leaving a large number of nonperforming loans to be resolved by the Slovak Consolidation Agency), and introduction of reforms to bring the sector into line with European Union standards. As of end-2006, there were 24 commercial banks in Slovakia. The market shares of the three and five largest banks were, respectively, around 50 and 65 percent. Most commercial banks offer both retail and wholesale banking services. 
41. While there has been significant recent expansion in the extension of credit to households, the financial condition of the banking system remains sound. However, the market is competitive and lenders are assuming somewhat higher credit risks in pursuit of market share. The response of the National Bank of Slovakia (NBS) has been to improve data collection, monitor risk management practices of banks more closely, and to interact regularly with home supervisors of foreign-owned banks. As of end-2006: the aggregate NPL loan ratio was 3.2 percent; the ratio of NPLs net of provisions to capital was 7.9 percent; the banking system ROA was 1.3 percent; the banking system ROE was 16.6 percent; and the liquidity ratio was 36.5 percent.

\section{Main Findings}

\section{Preconditions for effective banking supervision}

42. Substantial progress has been made in the last few years in improving the legal framework of Slovakia. Tax reform, effective January 1, 2004, introduced a uniform corporate and personal income tax rate of 19 percent. Amendments to the Civil Code, effective from January 1, 2003, substantially improved the law on collateral and generally on secured transactions. Other improvements concern new investment incentives and legislation and corporate governance changes to the Commercial Code. At the beginning of 2006, a new Bankruptcy Act became effective, establishing a pro-creditor oriented bankruptcy system and emphasis on the restructuring process for insolvent debtors as opposed to bankruptcy proceedings. Several amendments were passed designed to reform the court system and strengthen the status of the courts, the latest effective as of January 1, 2006, with the primary goal of speeding up the procedure before the civil courts.

\section{The general legal, business, and accounting framework within which banks} operate and banking supervision takes place is developing well. Market discipline is effective, primarily because the market is well served by participants based in major economies. The NBS, as supervisory authority, has an array of powers to control the risks assumed by the banks. The independence of the supervisory authority is, in practice, good. The NBS has extensive authority to license, supervise, and inspect all institutions as well as power to establish prudential safety and soundness standards and regulations. The supervisory authority appears to possess an adequate number of staff to provide timely, comprehensive on- and off-site supervision to the current group of licensees. Sufficient legal protections are in place to enable NBS supervisory staff to perform their functions effectively.

\section{Objectives and powers}

44. The NBS is empowered as the bank supervisory, regulatory, and licensing authority in Slovakia by virtue of "The Act on the National Bank of Slovakia" (NBSA). 
In January 2006, supervision of the entire financial sector was unified under the NBS. ${ }^{14}$ The NBS operates a comprehensive, transparent system in exercising its exclusive right to grant banking licenses, and to maintain observance of bank legislation and regulations. This has contributed substantially to the current state of development of the financial system.

\section{Licensing and structure}

45. The banking activities, the use of the term "bank," and the supervisory means of protecting sound ownership and structure of banks are all clearly defined. "Act No. 483/2001 Coll. on Banks and Amending and Supplementing Certain Acts" (the "Banking Act" or "BA") defines permissible activities and the term "bank." The latter statute also prohibits use of the term "bank" and its derivatives except by institutions regulated by the NBS.

46. The NBS has the specific legal authority to require its prior review of, and approval for, the proposed acquisition of a significant shareholder interest in an established bank, and has the capacity to require disclosure the source of the acquirer's funds and apply a "fit-and-proper" test. Criteria for establishing banks and approving the scope of their operations also requires determination of the source of the funds, with which the incorporator capitalizes the licensee and, as well, application of the "fit-and-proper" test for owners and senior managers, which approximates that usual in the international marketplace. That said, the NBS does not have the power to require changes in composition of the statutory body and senior management to address any prudential concerns related to satisfaction of criteria cited in the Banking Act dealing with corporate governance. Similarly, there is no requirement that banks notify the NBS when they become aware of material evidence which may negatively affect the "fit and proper" status of a member of the statutory body, the supervisory board, or a senior officer.

47. So long as an aggregate investment is below the quantum limit of 20 percent of "own funds" of the investee bank, there is no requirement that incorporation or acquisition of a subsidiary in a business related to banking be brought to the attention of the NBS for its approval. The NBSA prohibits a bank from taking a control position in a nonfinancial company and limits investment in one such enterprise to 15 percent of own funds, with an aggregate limit of 60 percent.

\footnotetext{
${ }^{14}$ Until that time, the NBS had been responsible for bank supervision. Supervision of the insurance sector, the capital markets and pensions funds had been the responsibility of the Slovak Financial Markets Authority.
} 


\section{Prudential regulations and requirements}

48. Market risk-related computations, capital charge, and necessary reporting requirements are in force in the Slovakia. Risk-weighted capital adequacy requirements are applied on both a "solo" and "consolidated" basis. However, there is an uncertainty whether, and to what extent, the NBS can impose additional capital requirements if appropriate to deal with particular risk profiles (e.g., for non-arm's length exposures or "hidden" losses or other situations where "prudential filters" are required) on a case-by-case basis.

\section{General requirements for risk management processes and procedures are} stipulated by the NBS's decree on risk management and risks. Determining the efficiency of risk management as well as management oversight and assessing the inherent risks taken by an institution are an integral part of the NBS's ongoing off-site and on-site supervision. Credit risk - although still relatively modest - is the predominant risk in the Slovak banking sector. Market risks are low, and country and transfer risk are almost nonexistent. Although there are no specific requirements for the management of interest rate risk in the banking book, proper management of interest rate risk is verified by the NBS. The management of liquidity risk is as covered by a special decree issued by the NBS. While the NBSA requires that senior management must address all significant internal operations in order to create an effective comprehensive internal control system and the NBS has detailed inspection procedures to assess adequacy of banks' internal control systems, the NBS has not yet issued a decree on the matter.

\section{Abuse of financial services}

50. The Slovak Republic has implemented the relevant EU anti-money laundering legislation. As a member of the Council of Europe's Committee of Experts on the Evaluation of Anti-Money Laundering Measures (MONEYVAL), the Slovak Republic observes most of the FATF 49 Standards. The Slovak Republic has established a financial intelligence unitthe Financial Intelligence Unit of the Bureau of Organized Crime (SJFP-UBPOK) — which is a member of the Egmont Group. Financial professions, in the broadest sense, are required to report suspicious transactions to the SJFP-UBPOK. Account opening procedures require formal identification of the account holder. Banks are obliged to refuse execution of transactions from clients on an anonymous basis and to determine the ownership of funds used by customers for every transaction in excess of EUR 15,000. That said, a recent peer review by MONEYVAL indicated that some gaps remain in the AML framework and these should be addressed 


\section{Methods of ongoing supervision}

51. The off-site supervision and on-site inspections of the NBS are based on appropriate procedures. On-site inspections are planned as a result of the off-site analysis of regulatory reporting and extended reports from external auditors, and carried out using standardized, written procedures. In recent years, effective measures to enhance the quality of supervision have led to a significantly better understanding of the risk profiles of supervised institutions and put the NBS in the position to shift its focus from comprehensive to more targeted inspections. The NBS has in place a standardized system for rating the overall condition of a bank under its supervision. While regular formal contacts between the NBS and management of banks is not an integral part of the NBS's supervisory activities, such meetings are held on an "as required" basis. The NBS has full authority to request any information needed in the exercise of its supervision.

52. The various prudential reports are submitted both in electronic (online) and hard copies, promptly reviewed for accuracy, and then used as inputs by the off-site supervision section for analysis and any required follow-up. The NBS ensures that information provided from bank records is verified periodically through on-site inspections. In addition to its on-site inspections, the NBS uses extended format reports which require banks to commission annually from their external auditors as a significant source of supervisory information. Licensees are required to produce audited financial statements and annual reports pursuant to special regulations - Regulation (EC) 1606/2002 of the European Parliament and Council on the application of International Accounting Standards (IFRS), and the NBS has power to reject the (annual) appointment of a bank's external auditor.

53. Remedial measures of the NBS are in place. Article 50 of the BA provides the NBS a comprehensive array of remedial measures in the event a bank fails to comply with prudential rules. However, the NBS does not have the power to disqualify executive board members and members of senior management of existing banks. Furthermore, for the time being, it lacks the legal power to impose additional capital requirements on an institution to make adjustments to unusual risk profiles or deficiencies of risk management. It is unclear, if and to what extent, the lack of these legal powers might be compensated by the use of moral suasion.

54. The NBS has sufficient legal powers and resources to exercise supervision on a consolidated and sub-consolidated basis. Consolidated supervision, however, is not of major importance, due to the transparency and limited complexity of groups subject to the NBS's supervision. By contrast, cross-border cooperation and exchange of information with other relevant supervisors are of vital interest for the NBS as the host supervisor of a relatively small banking sector that is almost fully owned by foreign banks. The BA provides the necessary legal framework to cooperate with foreign supervisors, exchange information, 
and share supervisory tasks in ongoing supervision and in crisis situations. The NBS has the necessary supervisory tools and expertise not only to fulfill competently its task as the domestic institutions' supervisor, but as well to efficiently support the consolidated supervisor to perform its tasks. While the NBS has the authority to supervise the overseas activities of locally incorporated banks, this is not presently of importance, given the lack of such activity. Local branches of foreign banks are, in principle, subject to the same prudential, inspection, and reporting requirements as domestic banks. However, most of the branches are of banks from other EU countries, and, therefore, only subject to the home supervisors prudential supervision according to the Single European Passport Regime.

\section{Recommended Action Plan}

55. The NBS is compliant or largely compliant with all the Basel Core Principles but, in the opinion of the assessors, the supervisory system would benefit from the additional measures listed below.

Table 4. Recommended Action Plan to Improve Compliance of the Basel Core Principles

\begin{tabular}{|l|l|}
\hline \multicolumn{1}{|c|}{ Reference Principle } & \multicolumn{1}{|c|}{ Recommended Action } \\
\hline CP6. Capital Adequacy & $\begin{array}{l}\text { Provide clear statutory power to NBS to impose } \\
\text { additional regulatory capital requirements to deal with } \\
\text { particular risk profiles or to reduce regulatory capital } \\
\text { (e.g., for non-arm's length exposures or "hidden" } \\
\text { losses, or other situations where "prudential filters" are } \\
\text { required) on a case-by-case basis. It is understood that } \\
\text { such power will be granted as a result of the } \\
\text { transposition of the CRD into Slovak law. However, it } \\
\text { has to be closely monitored whether such power is } \\
\text { sufficiently defined to avoid legal challenges and } \\
\text { whether it is executable in practice. }\end{array}$ \\
\hline CP9. Problem Assets, Provisions, and Reserves & $\begin{array}{l}\text { Reduce ambiguity from the lack of a clear segregation } \\
\text { of responsibility between the NBS and the external } \\
\text { auditors. Make a clear distinction between capital } \\
\text { provisions/reserves for accounting and regulatory } \\
\text { purposes. Closely monitor the effect of IFRS on } \\
\text { provisioning. }\end{array}$ \\
\hline CP16. Interest Rate Risk in the Banking Book & $\begin{array}{l}\text { Consider addressing interest rate risk in the banking } \\
\text { book explicitly through secondary legislation. }\end{array}$ \\
\hline CP17. Internal Control and Audit & $\begin{array}{l}\text { Provide the NBS power to remove persons who are } \\
\text { subject to fit-and-proper testing according to the } \\
\text { Banking Act to address prudential concerns resulting } \\
\text { from such persons' integrity or performance of their } \\
\text { duties immediately. }\end{array}$ \\
\hline
\end{tabular}




\section{Authorities' response}

56. The Slovak authorities were in broad agreement with the assessment. In addition, to providing a number of technical suggestions and corrections, in response to the FSAP team's recommendations, they however noted that the legislation implementing the EU Capital Requirements Directive in Slovakia (the amendment to the Banking Act), which took effect from January 1, 2007, addressed the FSAP mission's recommended action as regards capital adequacy (CP6). The amendment also addressed also the FSAP mission's recommendation related to CP9 (on problem assets, provisions and reserves) because it provides a new, specific, authority for enforcement to the NBS, under which a bank is obliged to reassess its provisioning if the NBS finds that the level of provisioning does not reflect the factual situation. Finally, the amendment impacts on the assessment of CP16, on interest rate risk in the banking book, and the related recommendation. The Banking Act, as now amended, provides the NBS with the authority to issue specific secondary legislation, which has since been done and which took effect from 15 January 2007, clarifying the issue of interest rate risk in the banking book.

\section{B. Summary Assessment of Observance of the Insurance Core Principles}

57. The assessment of the observance of the Insurance Core Principles (ICP), carried out as part of the FSAP update mission to the Slovak Republic, was conducted in December 2006 based on the principles approved by the International Association of Insurance Supervisors (IAIS) in October 2003. It reflected the insurance supervision practices of the Slovak Republic authorities as of end-November 2006.

\section{Since the 2002 FSAP, insurance supervision has shown an impressive} improvement. Most of the 2002 recommendations have been followed up by implementing the European Union insurance directives in national legislation. The insurance supervisory staff of the NBS appreciates the formal meaning as well as the spirit of the EU directives. The collaboration with the Ministry of Finance in implementing the directives has proven to be effective. As a result, insurance supervision is generally compliant with the ICP.

\section{Institutional and macroprudential setting-overview}

59. As of end-September 2006, there were 24 insurance companies operating in Slovakia. During the last five years, the number of insurance companies has marginally decreased. While there were a few new entrants to the market, more companies have been either closed down or merged. Two largest companies have a combined market share of over 50 percent of the total gross written premium. 
60. Nearly all insurance companies are foreign-owned and often part of well reputed large insurance groups or financial conglomerates. Accordingly, the insurance supervisor puts a lot of effort into international cooperation with home supervisors, in order to understand and communicate the possible vulnerabilities arising from a cross-border context. ${ }^{15}$

\section{Premium growth per capita is in line with general expectations and can be} considered a consequence of general economic growth, rather than a condition thereof. The share of savings via life assurance is rather small; the modest size of the capital market does not seem to be a limiting factor to date. It is to be expected that the need for insurance products will gradually grow for both life and non-life products. Stronger competition is expected via the distribution channels

\section{General preconditions for effective insurance supervision}

\section{The institutional arrangements for insurance supervision have changed} considerably in recent years. Initially, insurance supervision was the responsibility of the Ministry of Finance. It was later moved to the Financial Market Authority (FMA) which was, from January 2006, in turn absorbed into the NBS. The reasoning behind this latter move was that financial supervision could become more independent from government and that a more efficient allocation of supervisory resources across financial subsectors could be more easily realized in an integrated supervisor.

63. Further reorganization of supervision within the NBS is expected to take place in 2007. In particular, regulatory resources are expected to be allocated functionally rather than on the current sectoral basis. However, such a functional allocation of resources may not be completely compatible with legislation (bank, insurance, pensions, and security laws are distinct), and actual market structures. In order to achieve maximum advantages of functional and integrated supervision, it is therefore recommended that:

- $\quad$ it be made clear to stakeholders in the financial sector that insurance supervision is still an important part of the NBS' responsibilities under any new organizational arrangement; and

- a fruitful cooperation between supervisors within the NBS should be based on disseminating to the staff the general supervisory purposes and expertise, such as

\footnotetext{
${ }^{15}$ Generally, within the EU from where many of the parents of Slovak insurance companies originate, protocols between the supervisory authorities exist (i.e., the Helsinki Protocol and the Siena Protocol), underpinned by EU Directives, which allow for a timely and adequate flow of information between insurance supervisors. The NBS has the power to conclude formal information sharing agreements with non-EU insurance supervisory agencies, however such agreements are not a pre-requisite for information sharing.
} 
assessing typologies of different risks, asset liability modeling, investment analysis, exercising stress tests, market conduct, and common standards for the assessment of the fitness and propriety of the management and owners of financial institutions.

64. This assessment took place against a background of a strong macroeconomic performance. As a result of expectations of good growth prospects and low inflation, interest rates have been falling over the last few years. As technical provisions for many older life policies with guaranteed capital were calculated assuming higher (less prudent) discount rates the provision for these policies is insufficient. The insurance supervisory staff are aware of this issue. Nonetheless it is recommended that the solvency requirements for these life insurance policies be enhanced.

65. Insurance fraud undermines the reputational standing of insurance markets and leads to welfare losses because of suboptimal premiums. To avoid such a problem arising, it is recommended that the association of insurers, the criminal police, and the NBS should cooperate more intensively.

\section{Main findings}

66. The internal and external auditors as well as actuaries currently play limited roles in the supervisory framework. A consequence is that the duties and responsibilities of the insurance supervisor are relatively heavy compared to other jurisdictions. It is therefore recommended that the NBS start a process of rebalancing the necessary supervisory work of insurance companies in a way by defining and expanding what is expected from the external auditor and actuary. One way to achieve this could be by establishing in legislation the statutory role of these professionals, including obligations and legal immunities, fit and proper criteria, code and conduct, and the NBS' power to approve and remove these key functionaries.

67. The powers of the NBS to supervise the fitness and propriety of the owners of insurance companies need to be strengthened. It is also recommended that the NBS strengthen supervision of tied agents by focusing on the market conduct of these intermediaries according to EU laws. With respect to consumers in their own jurisdiction, the supervisory authority should set requirements with which insurers and intermediaries must comply. The requirements applicable to cross-border sales should also be clear.

\section{Recommended Action Plan}

68. The NBS is generally compliant with the ICPs but, in the opinion of the assessor, the supervisory system would benefit from the additional measures listed below: 
Table. Recommended Action Plan to Improve Observance of IAIS Insurance Core Principles

\begin{tabular}{|c|c|}
\hline Reference Principle & Recommended Action \\
\hline $\begin{array}{l}\text { Conditions for effective insurance } \\
\text { supervision } \\
\text { i.e., CP } 1\end{array}$ & $\begin{array}{l}\text { Expand the mandate of insurance companies' external } \\
\text { auditors to provide information to the NBS, in line with } \\
\text { the requirements placed on external auditors of banks. }\end{array}$ \\
\hline $\begin{array}{l}\text { Suitability of persons } \\
\text { i.e., CP } 7\end{array}$ & $\begin{array}{l}\text { Provide the NBS with strengthened powers to take actions } \\
\text { against new owners of existing insurance businesses, so as } \\
\text { to ensure fitness and propriety including the power to } \\
\text { require that owners dispose of their interests. }\end{array}$ \\
\hline $\begin{array}{l}\text { Internal control } \\
\text { i.e., } \mathrm{CP} 10\end{array}$ & $\begin{array}{l}\text { Introduce through legislation a stronger statutory role for } \\
\text { actuaries and auditors in the supervisory process including } \\
\text { legal requirements for information disclosure to the } \\
\text { supervisor by actuaries and internal auditors. }\end{array}$ \\
\hline $\begin{array}{l}\text { Risk assessment and management } \\
\text { i.e., CP } 18\end{array}$ & $\begin{array}{l}\text { Strengthen requirements covering risk assessments by } \\
\text { insurance companies; starting in } 2008 \text {, all insurers will be } \\
\text { required to calculate a wider selection of risk ratios. }\end{array}$ \\
\hline $\begin{array}{l}\text { Investments } \\
\text { i.e., CP } 21\end{array}$ & $\begin{array}{l}\text { Strengthen expertise within NBS regarding assessment of } \\
\text { market, credit, matching and operational risks. } \\
\text { Cooperation with the investment experts within the NBS } \\
\text { can enhance the future quality of supervision in a manner } \\
\text { consistent with the philosophy of Solvency II. }\end{array}$ \\
\hline $\begin{array}{l}\text { Derivatives and similar commitments } \\
\text { i.e., CP } 22\end{array}$ & $\begin{array}{l}\text { Require insurance companies to adopt and clearly disclose } \\
\text { comprehensive policies on the use of derivatives and to } \\
\text { have appropriate risk management systems and internal } \\
\text { controls in place (investments in derivatives by Slovak } \\
\text { insurance companies have been modest to date, so that } \\
\text { this recommendation is not currently critical). }\end{array}$ \\
\hline $\begin{array}{l}\text { Capital adequacy and solvency } \\
\text { i.e., CP } 23\end{array}$ & $\begin{array}{l}\text { Consider establishing and communicating a solvency } \\
\text { control level in excess of the minimum solvency margin, } \\
\text { particularly if it appears that the implementation of } \\
\text { Solvency II will need to be delayed. }\end{array}$ \\
\hline $\begin{array}{l}\text { Consumer protection } \\
\text { i.e., CP } 25\end{array}$ & $\begin{array}{l}\text { Allocate sufficient resources to enable the NBS to } \\
\text { adequately supervise the market conduct of intermediaries } \\
\text { and agents that sell insurance products. } \\
\text { Insure that insurance companies, intermediaries and } \\
\text { consumers are all fully aware of the legal conditions } \\
\text { concerning market conduct and disclosure requirements } \\
\text { for insurance products. }\end{array}$ \\
\hline
\end{tabular}




\section{Authorities' response}

69. The Slovak authorities were in broad agreement with the assessment. In addition, to providing a number of technical suggestions and corrections, in response to the FSAP team's recommendations regarding suitability of persons (CP7) they noted that each new owner of an existing insurance undertaking has to have a prior approval by the National Bank of Slovakia. If a natural person or a legal person obtains a share in the registered capital of the insurance undertaking without a prior approval, the National Bank of Slovakia has the power to suspend the exercise of its right to participate in and vote at the General Meeting of the insurance company.

70. The authorities also noted that the National Bank of Slovakia is at the moment collaborating with the Ministry of Finance in the process of changing the Insurance Act. This is being done, besides some other reasons, in order to implement some of the FSAP team's recommended actions as soon as possible. Also, from February 1, 2007, a new section has been formed within the National Bank of Slovakia's structure responsible especially for supervision of insurance mediation 


\section{APPENDIX I: SLOVAK REPUBLIC: STATUS OF THE MAIn RECOMMENDATIONS OF THE 2002 FSAP}

\begin{tabular}{|c|c|}
\hline Recommendations & Status \\
\hline \multicolumn{2}{|l|}{ Financial Sector Supervision } \\
\hline Strengthen cross-border prudential supervision. & Ongoing \\
\hline $\begin{array}{l}\text { Strengthen the supervision of nonbank financial institutions, } \\
\text { which are modest in size but growing rapidly. }\end{array}$ & Ongoing \\
\hline $\begin{array}{l}\text { Apply same standards of disclosure and transparency used for } \\
\text { financial institutions to the existing supplementary pension } \\
\text { insurance fund management companies, and to the pension } \\
\text { management companies (second pillar) that will emerge as part } \\
\text { of pension reform. }\end{array}$ & $\begin{array}{l}\text { A new regulation on voluntary pension schemes was approved in } 2005 \\
\text { that addressed most of the regulatory issues raised in the } 2002 \text { FSAP. } \\
\text { A law approved in December } 2006 \text { leaves some providers of voluntary } \\
\text { savings in a less competitive situation. }\end{array}$ \\
\hline \multicolumn{2}{|l|}{ Insolvency and Creditor Rights Framework } \\
\hline $\begin{array}{l}\text { Adopt new comprehensive insolvency legislation that improves } \\
\text { efficiency, follows international best practice, and introduces a } \\
\text { functional rehabilitation scheme. }\end{array}$ & $\begin{array}{l}\text { At the beginning of 2006, the new Bankruptcy Act came into effect } \\
\text { which is more creditor friendly, and emphasizes the restructuring of } \\
\text { insolvent debtors as opposed to bankruptcy proceedings. } \\
\text { Several amendments have been passed to reform the court system- } \\
\text { including a January } 2006 \text { amendment to speed up court proceedings- } \\
\text { but it remains inefficient. }\end{array}$ \\
\hline \multicolumn{2}{|l|}{ Accounting Standards } \\
\hline $\begin{array}{l}\text { Bring Slovak accounting standards and practices in line with } \\
\text { International Accounting Standards, to allow investors and } \\
\text { creditors to make meaningful use of financial statements. }\end{array}$ & $\begin{array}{l}\text { FSAP recommendations on IFRS have been fully implemented. } \\
\text { Applicable regulations require the use of IFRS, as endorsed by the } \\
\text { European Union, for the preparation of individual and consolidated } \\
\text { accounts of banks, insurance and listed companies. Financial } \\
\text { statements now meaningfully express financial condition and } \\
\text { performance. }\end{array}$ \\
\hline \multicolumn{2}{|l|}{ Deposit Protection Fund (DPF) } \\
\hline $\begin{array}{l}\text { The Ministry of Finance should consider providing the DPF with } \\
\text { a combination of equity and loan funds that will improve the } \\
\text { financial condition of the DPF and allow a return to a more } \\
\text { reasonable level of deposit insurance premiums for healthy banks } \\
\text { and establishing, together with the NBS, a formal line of credit } \\
\text { for the DP. }\end{array}$ & $\begin{array}{l}\text { Funding for the SDIF funds shortfall is currently provided by a } \\
\text { consortium of banks (previously by the NBS). In the event of a need } \\
\text { for further funding, the expectation is that this would in the first } \\
\text { instance come from the NBS or commercial banks. The improving } \\
\text { financial position of the SDIF enabled a reduction in premiums from } \\
0.75 \text { percent of protected deposits to } 0.2 \text { percent in } 2006 \text {. }\end{array}$ \\
\hline \multicolumn{2}{|l|}{ Exit Policies } \\
\hline Strengthen exit policies for financial. & $\begin{array}{l}\text { Exit policies for financial institutions, as well as private enterprises } \\
\text { more generally, have been significantly improved. }\end{array}$ \\
\hline \multicolumn{2}{|l|}{ Credit Bureaus } \\
\hline $\begin{array}{l}\text { Develop credit bureaus to facilitate the expansion in consumer } \\
\text { finance, small sector lending, and leasing and housing finance. }\end{array}$ & $\begin{array}{l}\text { The regulatory framework has been modified. The corporate credit } \\
\text { registry operated by the NBS has been reorganized and subject to } \\
\text { major improvements. The three largest banks have established a } \\
\text { commercial register for retail finance with open access. This register } \\
\text { has } 16 \text { participants and is based on a state of art software and } \\
\text { communications platform. }\end{array}$ \\
\hline \multicolumn{2}{|l|}{ Public Debt Management } \\
\hline $\begin{array}{l}\text { Develop the primary and secondary markets for government } \\
\text { securities through strengthening public debt management, by } \\
\text { reducing the number of issues, bringing the issue policy in line } \\
\text { with the overall objectives of debt management, and increasing } \\
\text { the role of the Ministry of Finance (MOF)in guiding the market } \\
\text { through regular dialogue. }\end{array}$ & $\begin{array}{l}\text { Important improvements in public debt management have taken place } \\
\text { since } 2002 \text {. Debt is managed by a specialized agency (ARDAL), and } \\
\text { strategic decisions are taken by the MOF. Maturities have increased } \\
\text { significantly, and the size of bonds on issue is at least SKK } 40 \text { billion. } \\
\text { Yearly calendars for auctions and types of bond issues are published as } \\
\text { is the debt management strategy. A number of issues remain: } \\
\text { secondary market of government securities has remained illiquid; the } \\
\text { number of issues is rather large; coordination between the MOF, } \\
\text { ARDAL, and the NBS should be improved. }\end{array}$ \\
\hline \multicolumn{2}{|l|}{ Housing Finance } \\
\hline Rationalize fiscal incentives to encourage housing finance. & $\begin{array}{l}\text { The incentives were removed in 2005, but introduction of new } \\
\text { incentives in this area (mortgage subsidies) is being contemplated. }\end{array}$ \\
\hline
\end{tabular}




\section{APPENDiX II: STRESS TeSTS: OVERVIEW OF THE SHOCKS AND RESUlTS}

1. The stress tests conducted during the FSAP update were based on methodology and scenarios proposed by the FSAP team and discussed with NBS. Using the data as of end-September 2006, the tests were conducted individually for all 17 commercial banks incorporated in the Slovakia. The stress tests included sensitivity analysis of the banking sector exposure to interest rate, exchange rate, real estate price, credit, and liquidity risks. Macroeconomic scenarios involving a combination of shocks were also considered based on a vector autoregression model, but given the shortage of time-series data the model was not sufficiently robust and therefore the results of these scenarios are not reported here. The size of the various shocks used in the stress testing exercise was chosen based on both historical and hypothetical changes in the shocked key variables.

2. The results of the tests can be summarized as follows:

- $\quad$ Credit risk potentially has a relatively large impact on banks. An increase in NPLs under assumptions of either no growth in total credit or credit boom with relaxed lending standards, or a outright doubling in NPLs, would lead to a decline in the aggregate Tier I capital adequacy ratio by 16 to 21 percent. All tests use a conservative assumption of loss given default of 100 percent.

- $\quad$ Banks become increasingly sensitive to a large koruna interest rate shock, especially to a steepening in the koruna yield curve. This sensitivity can be attributed to an increase in the banks' portfolios of fixed interest rate debt securities with long maturities.

- $\quad$ Exposures to exchange rate risk and foreign interest rate risk are insignificant. This is not surprising, given the relatively low share of foreign currency-denominated assets and liabilities.

- $\quad$ Direct losses arising from a collapse in the real estate market would be negligible for almost all banks. A 50 percent fall in the property prices would lead to a decline in the Tier I capital adequacy ratio by only 5 percent. Despite the stagnation of the real estate market following the EU entry in 2004, after strong rises in the immediately preceding period, such a small impact may be attributed to prudent (albeit increasing) loan-to-value ratios and a still relatively small penetration of mortgages.

- $\quad$ Effects of stress scenarios on liquidity ratios are not significant. A depreciation of government bonds would not have any major effect on banks' liquidity ratios, and the exposure to liquidity risk is related mainly to the possibility of sudden deposit withdrawals. 
Table 5. Slovak Republic: Summary Results of the Stress Tests (1) (Based on the data of September 30, 2006)

\begin{tabular}{|c|c|c|c|}
\hline Test & Aggregate results & Best bank & Worst bank \\
\hline & \multicolumn{3}{|c|}{$\begin{array}{c}\text { Impact on Tier I Capital } \\
\text { (in percent) } \\
\text { (negative value means decrease) }\end{array}$} \\
\hline \multicolumn{4}{|l|}{ Interest rate risk } \\
\hline Parallel upward shift in the SKK yield curve by 500 bp & -23.2 & 37.6 & -74.0 \\
\hline Slopening of the SKK yield curve $1 /$ & -0.8 & 1.3 & -2.8 \\
\hline Steepening of the SKK yield curve 2/ & -18.1 & 31.3 & -68.3 \\
\hline Parallel upward shift in the Euro yield curve by $150 \mathrm{bp}$ & -1.8 & 0.0 & -6.5 \\
\hline Parallel upward shift in SKK and EUR interest rates by 200 bp & -13.3 & 15.8 & -34.5 \\
\hline \multicolumn{4}{|l|}{ Exchange rate risk } \\
\hline Depreciation of the SKK/Euro rate by 4.10 percent 3 / & -0.2 & 1.0 & -1.6 \\
\hline Depreciation of the SKK/US\$ rate by 7.86 percent $4 /$ & 0.0 & 3.6 & -1.7 \\
\hline Depreciation of the SKK against all currencies by 20 percent & -0.8 & 1.4 & -3.3 \\
\hline \multicolumn{4}{|l|}{ Real estate price risk } \\
\hline Fall in the residential and commercial real estate prices by 50 percent & -5.0 & 0.0 & -18.5 \\
\hline \multicolumn{4}{|l|}{ Credit risk } \\
\hline No credit growth $5 /$ & -17.1 & -0.2 & -102.1 \\
\hline Granting of loans with highest default rate $6 /$ & -16.4 & 0.0 & -66.0 \\
\hline Increase in NPLs by 100 percent & -21.2 & -0.1 & -73.8 \\
\hline \multicolumn{4}{|l|}{ Memorandum items: } \\
\hline Baseline Tier I Capital Ratio (in \% of risk-weighted assets) & 13.8 & 26.2 & 7.5 \\
\hline
\end{tabular}

1/ Increase in short-term SKK interest rates by $500 \mathrm{bp}$.

2/ Increase in long-term SKK interest rates by $500 \mathrm{bp}$.

3/ Equivalent to the largest increase in the SKK/Euro rate within 10 business days during 2004-05.

4/ Equivalent to the largest increase in the SKK/US\$ rate within 10 business days during 2004-05.

5/ Largest monthly absolute increase in NPLs during January-September 2006, multiplied by a coefficient of 5 (corresponding to increase in NPLs by $80 \%)$.

6/ Increase in loans by the average monthly increase in 2006 multiplied by a coefficient of 12 (i.e. annualized), with a highest share of NPLs recorded in 2006, multiplied by a coefficient of 3 (corresponding to increase in NPLs by $80 \%$ and increase in tot 


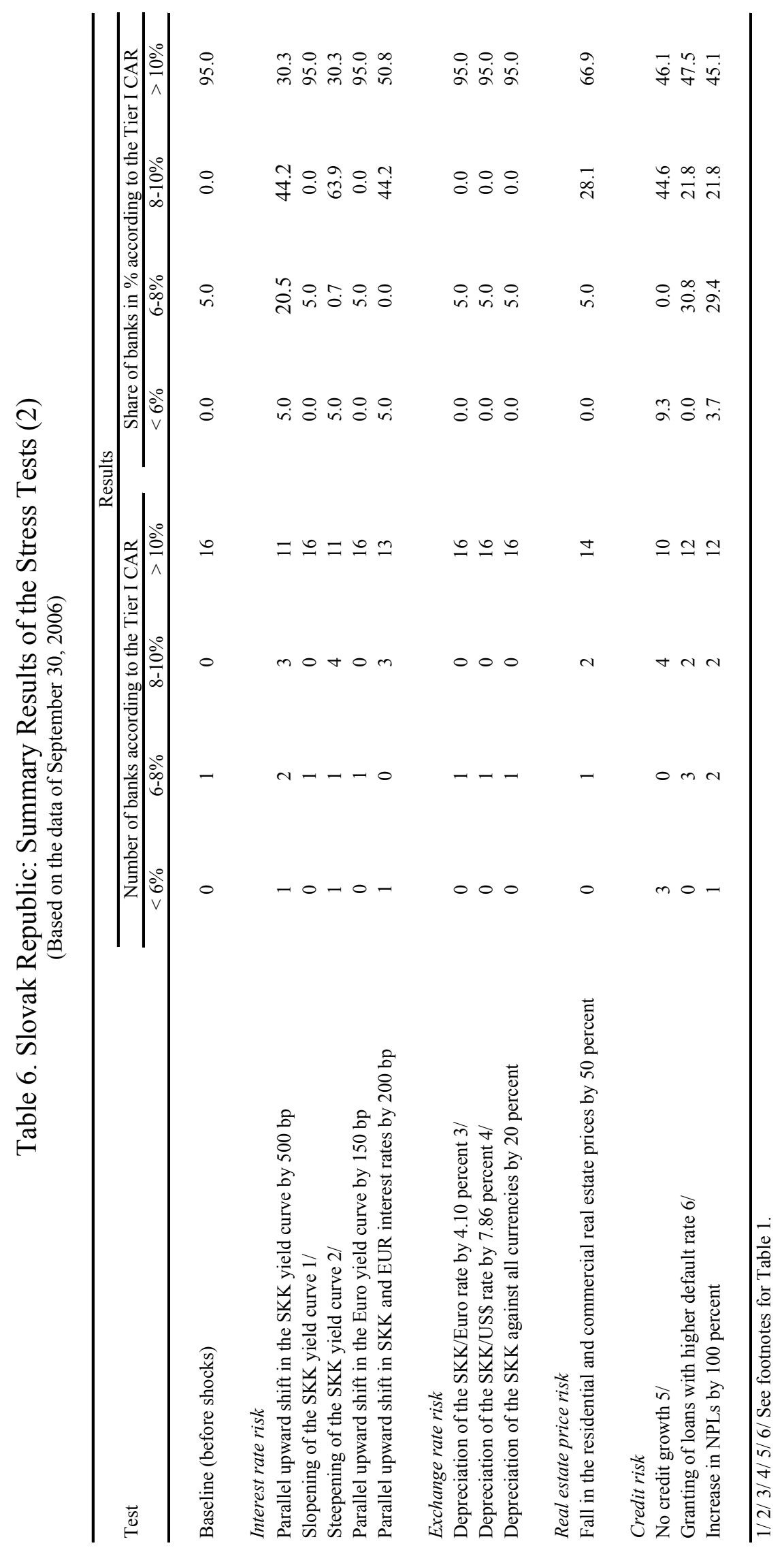


Table 7. Slovak Republic: Summary Results of the Liquidity Stress Tests

(Based on the data of September 30, 2006)

\begin{tabular}{|c|c|c|c|}
\hline Test & Median & Lower quartile & Upper quartile \\
\hline Liquidity risk & \multicolumn{3}{|c|}{ Impact on of quick liquidity (in \%) $1 /$} \\
\hline Depreciation of government bonds by 10 percent & 13.2 & 1.1 & 41.8 \\
\hline Decline in client deposits by 20 percent & 158.4 & 51.5 & 243.4 \\
\hline \multirow[t]{2}{*}{ Outflow of short-term capital from the banking sector by 90 percent } & 122.7 & 19.2 & 255.0 \\
\hline & \multicolumn{3}{|c|}{ Impact on liquidity up to 7 days (in \%) $1 /$} \\
\hline Depreciation of government bonds by 10 percent & 9.2 & 3.2 & 26.5 \\
\hline Decline in client deposits by 20 percent & 97.1 & 58.1 & 164.3 \\
\hline \multirow[t]{2}{*}{ Outflow of short-term capital from the banking sector by 90 percent } & 61.3 & 2.2 & 156.4 \\
\hline & \multicolumn{3}{|c|}{ Impact on liquidity up to 3 months (in \%) $1 /$} \\
\hline Depreciation of government bonds by 10 percent & 9.2 & 5.1 & 22.7 \\
\hline Decline in client deposits by 20 percent & 46.1 & 17.5 & 121.1 \\
\hline Outflow of short-term capital from the banking sector by 90 percent & 1.3 & 0.0 & 88.8 \\
\hline \multicolumn{4}{|l|}{ Memorandum items: } \\
\hline Average monthly absolute change of ratio of quick liquidity & 18.4 & 14.8 & 25.6 \\
\hline Average monthly absolute change of liquidity up to 7 days & 19.5 & 14.4 & 36.7 \\
\hline Average monthly absolute change of liquidity up to 3 months & 16.4 & 11.7 & 32.6 \\
\hline
\end{tabular}

Table 8. Slovak Republic: Summary Results of the Stress Tests, 2004-06 (Losses in percent of Tier I capital)

\begin{tabular}{lcccc}
\hline Test & Dec-2004 & Jun-2005 & Dec-2005 & Sep-06 \\
\hline & & & & \\
Parallel upward shift in the SKK yield curve by 500 bp & n.a. & 17.2 & 19.5 & 23.2 \\
Depreciation of the SKK against all currencies by 20 percent & 1.7 & 3.1 & 3.1 & 0.8 \\
Increase in NPLs by 100 percent & n.a. & 29.4 & 26.8 & 21.2 \\
\hline
\end{tabular}

